\title{
Assessment the impact of samplers change on the uncertainty related to geothermal water sampling
}

\author{
Katarzyna Wątor $^{1 *}$, Anna Mika ${ }^{1}$, Klaudia Sekuła ${ }^{1}$ and Ewa Kmiecik ${ }^{1}$ \\ ${ }^{1}$ AGH University of Science and Technology, Department of Hydrogeology and Engineering \\ Geology, Krakow, Poland
}

\begin{abstract}
The aim of this study is to assess the impact of samplers change on the uncertainty associated with the process of the geothermal water sampling. The study was carried out on geothermal water exploited in Podhale region, southern Poland (Małopolska province). To estimate the uncertainty associated with sampling the results of determinations of metasilicic acid $\left(\mathrm{H}_{2} \mathrm{SiO}_{3}\right)$ in normal and duplicate samples collected in two series were used (in each series the samples were collected by qualified sampler). Chemical analyses were performed using ICP-OES method in the certified Hydrogeochemical Laboratory of the Hydrogeology and Engineering Geology Department at the AGH University of Science and Technology in Krakow (Certificate of Polish Centre for Accreditation No. $A B$ 1050). To evaluate the uncertainty arising from sampling the empirical approach was implemented, based on double analysis of normal and duplicate samples taken from the same well in the series of testing. The analyses of the results were done using ROBAN software based on technique of robust statistics analysis of variance (rANOVA). Conducted research proved that in the case of qualified and experienced samplers uncertainty connected with the sampling can be reduced what results in small measurement uncertainty.
\end{abstract}

\section{INTRODUCTION}

All operation performed in the laboratory are biased by the systematic and random errors and all of them have contribution in the total uncertainty. It is estimated that during sampling process and samples transport to the laboratory almost $30 \%$ of errors arise. The process of samples treatment before analysis causes next $60 \%$ of errors, whereas the analysis is a source of about $10 \%$ of total sum of errors [1]. There are two methods of measurement uncertainty estimation. The first one, theoretical (bottom-up), relies on the quantitative assessment of selected sources of uncertainty one by one and in the next stage, their connection to total uncertainty. The second method, empirical (top-down), uses different parameters of analytical method determined during method validation or the results of analyses of control samples [2]. The empirical method is much common and is used more often. In this approach, four methods are used to measurement uncertainty estimation [2]:

- collection and analysis of duplicate samples (only random errors connected with sampling and analysis can be estimated);

\footnotetext{
${ }^{*}$ Corresponding author: wator@agh.edu.pl
} 
- use of different sampling protocols (random and systematic errors connected with sampling and random errors arising from analysis can be estimated);

- interlaboratory comparisons in sampling (both random and systematic errors connected with sampling and analysis can be estimated);

- proficiency testing in sampling (both random and systematic errors connected with sampling and analysis can be estimated).

The simplest and probably the cheapest method of uncertainty estimation is duplicate samples method. It can be carry out using balanced design (fig. 1) or its simplest form:

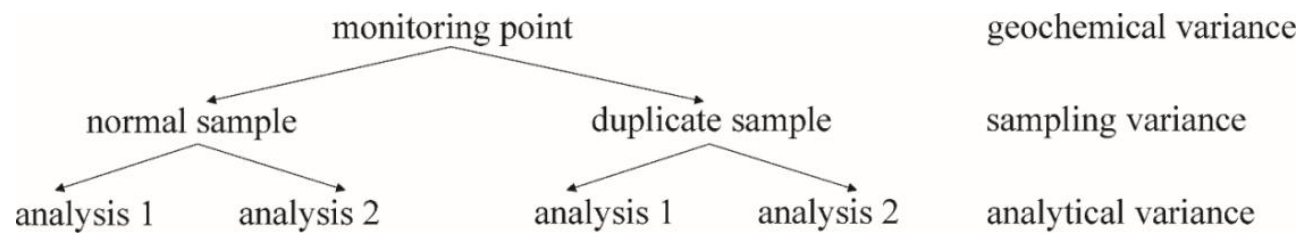

Figure 1. Balanced design schema for duplicate samples [3].

The main advantage of the use of the empirical method is that it takes into account all sources of uncertainty without necessity of their identification. This is universal, fast and easy method. However, it gives an approximate value of uncertainty [3]. The study was conducted to present how the uncertainty of geothermal water sampling changes in case of different samplers. The influence of sampler experience on the total uncertainty may e.g. change the water classification during assessment of curative water potential as it was indicated by Wątor et al. [4].

\subsection{Characteristic of the research area}

The research was carried out in southern Poland (Podhale region) in Małopolska province. Investigated geothermal water is classified as sulfate-chloride-sodium-calcium water (according to Szczukariew-Prikłoński classification). Mineralization of these waters is about $2.5 \mathrm{~g} / \mathrm{L}$, including specific component such as a metasilicic acid [5-8] and a temperature is between $82.9-86.3^{\circ} \mathrm{C}$ [9].

\section{MATERIALS AND METHODS}

Sampling was conducted between October 2014 to March 2016 in two-week intervals by two qualified samplers (tab. 1). Samples of geothermal water were collected directly on the wellhead according to procedure described in ISO 5667-11 standard [9] and methodology proposed by Witczak et al. [10] and Korzec et al. [11].

During sampling not only normal but also duplicate samples were collected. Control/duplicate samples were taken as duplicates of normal samples (8 pairs in each series) using the same technique.

Before the samples were collected, the unstable parameters $(\mathrm{pH}$, electrical conductivity and temperature) were measured in online system. Samples of geothermal water were filtered in the field with the use of microporous filters with pores diameter $0.45 \mu \mathrm{m}$ and also they were 
preserved with nitric acid (V). Then they were cooled below $4{ }^{\circ} \mathrm{C}$ and delivered to the laboratory in polyethylene, disposable containers.

Table 1. Scheme of sampling to assess the influence of sampler change on the uncertainty connected with sampling

\begin{tabular}{|l|c|c|}
\hline Sampler/Series & S1 & S2 \\
\hline Number of samples pairs (normal+duplicate) & 8 & 8 \\
\hline Period of samples collection & $10.2014-03.2015$ & $10.2015-03.2016$ \\
\hline Method of analysis & \multicolumn{2}{|c|}{ ICP-OES } \\
\hline Limit of silicon; determination (LOD) & \multicolumn{2}{|c|}{$0.1 \mathrm{mg} / \mathrm{L}$} \\
\hline $\begin{array}{l}\text { Measurement uncertainty declared by the laboratory* } \\
(\mathrm{k}=2,95 \%)\end{array}$ & \multicolumn{2}{|c|}{$12 \%$} \\
\hline
\end{tabular}

*including sampling

The chemical analysis were performed in the Hydrogeochemical Laboratory of the Hydrogeology and Engineering Geology Department at the AGH University of Science and Technology in Krakow (Certificate of Polish Centre for Accreditation No. AB 1050). Concentration of silicon was determined using ICP-OES method (inductively coupled plasma optical emission spectrometry - tab. 1) with the use of OPTIMA 7300DV spectrometer of PerkinElmer company according to PN-EN ISO 11885:2009 standard [12], and balanced design (fig. 1).

The measurement uncertainty declared by the laboratory (tab. 1) was estimated during validation of analytical procedure and the confirmation of their fitness for selected purposes. This uncertainty involves several factors arising from all steps of analytical procedure and vary dependent on the type of measure and the field of application [13]. Laboratory took into account all uncertainty sources — both random (precision) and systematic (accuracy) joint with sampling and analysis - during the combined standard uncertainty calculation.

There are known different methods of uncertainty estimation. The most common and probably the cheapest one is empirical approach (top down) based on analysis of control field samples and certified reference materials. In this paper the influence of sampler change on the uncertainty connected with geothermal water sampling is considered. In the literature it is indicated that the experience of sampler can affect the groundwater sampling uncertainty $[11,14-16]$.

Assessment of uncertainty can be conducted for particular measuring series by ROBAN software using robust ANOVA statistics, which allow $10 \%$ of outliers in analyzed database. The software calculates (on the base of results in normal and duplicate samples) three independent components of total variance: geochemical, sampling and analytical and their percentage (1):

$$
\underset{\text { total }}{2} \underset{\text { geochemical }}{2}+\underset{\text { sampling }}{2}+\underset{\text { analytical }}{2}
$$


Figure 2 shows limit values of relative parts of particular variances parts in total variance [17]. Percentage of geochemical variance should not be less than $80 \%$ and analytical variance should not be higher than $4 \%$ of total variance. Measurement variance - as a sum of analytical variance and sampling variance - should be lower than $20 \%$ [17].

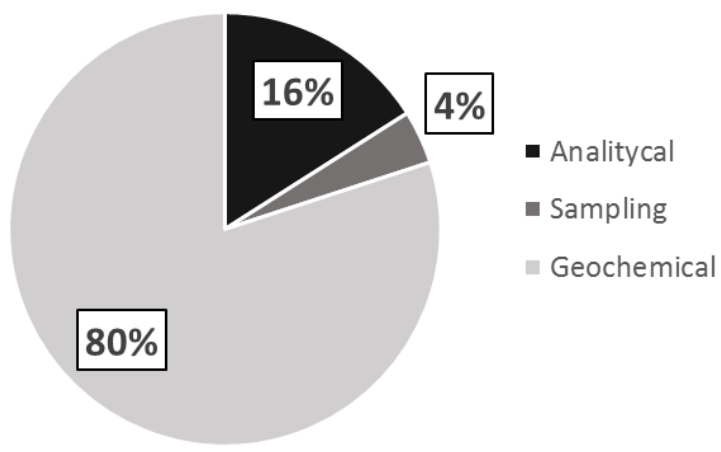

Figure 2. Percentage of particular variances in total variance ([17]- modified).

Additionally standard uncertainty $(u)$ connected with this factor can be calculated:

$$
\begin{aligned}
u_{\text {geochemical }} & =s_{\text {geochemical }} \\
u_{\text {sampling }} & =s_{\text {sampling }} \\
u_{\text {analytical }} & =s_{\text {analytical }} \\
u_{\text {measurement }} & =s_{\text {measurement }}
\end{aligned}
$$

To estimate expanded uncertainty $(U)$ at $95 \%$ confidence level, standard uncertainty supposed to be multiplied by coverage factor which is 2 [18]. The application provides also relative uncertainty $\left(U^{\prime}\right)$ which corresponds to mean value $(\bar{x})$ of analyzed indicators in normal and duplicate samples. The detailed information about calculation of expanded and relative uncertainty can be find in many publications, e.g. $[2,3,15,19]$.

When all samples are collected by the same person with the use of the same sampling protocol, systematic errors are minimised and the estimated uncertainty arising from sampling include only random effects. In this case, systematic errors should be additionally estimated, for example by using sampling reference materials or by taking into account results from proficiency testing in sampling.

\section{RESULTS AND DISCUSSION}

The silicon content in samples was recalculated to the concentration of the metasilicic acid and all further analysis and calculations were done for metasilicic acid.

In table 2 the values of particular elements in total variance are presented. For sampler S1 measurement variance exceeds almost $16 \%$ of total variance. Analytical variance in case of set $\mathrm{S} 1$ is around $8.75 \%$ of total variance whereas in series $\mathrm{S} 2$ it is $11.95 \%$, so in both cases it exceeds $4 \%$ showed on figure 2 .

In investigated geothermal water samples geochemical variance, which is connected with natural variability of metasilicic acid concentration, is the most visible. In both cases it is around $84-87 \%$ of total variance. Sampling variance is equal more than $7 \%$ for sampler S1 and is six times higher than for sampler S2 (1.19\%). 
Table 2. The variance values estimated based on results obtained from Roban software for metasilicic acid concentration in analysed geothermal water.

\begin{tabular}{|l|c|c|}
\hline \multirow{2}{*}{ Parameter } & \multicolumn{2}{c|}{ Calculated values } \\
\cline { 2 - 3 } & Sampler/Series S1 & Sampler/Series S2 \\
\hline Geochemical variance $[\mathrm{mg} / \mathrm{L}]^{2}$ & 6.25 & 15.21 \\
\hline Percentage of geochemical variance in total variance [\%] & 84.05 & 86.86 \\
\hline Sampling variance $[\mathrm{mg} / \mathrm{L}]^{2}$ & 0.536 & 0.209 \\
\hline Percentage of sampling variance in total variance [\%] & 7.20 & 1.19 \\
\hline Analytical variance $[\mathrm{mg} / \mathrm{L}]^{2}$ & 0.651 & 2.10 \\
\hline Percentage of analytic variance in total variance [\%] & 8.75 & 11.95 \\
\hline Measurement variance $[\mathrm{mg} / \mathrm{L}]^{2}$ & 1.19 & 2.31 \\
\hline Percentage of measurement variance in total variance [\%] & 15.95 & 13.14 \\
\hline
\end{tabular}

The values of uncertainty estimated on the basis of results from ROBAN software are presented in table 3 .

Table 3. The results of uncertainty of analysed geothermal water samples (calculated for metasilicic acid analysis) for two different samplers.

\begin{tabular}{|l|c|c|}
\hline \multirow{2}{*}{ Parameter } & \multicolumn{2}{|c|}{ Value } \\
\cline { 2 - 3 } & Sampler/Series S1 & Sampler/Series S2 \\
\hline $\bar{x}[\mathrm{mg} / \mathrm{L}]$ & 80.02 & 76.72 \\
\hline$u_{\text {total }}[\mathrm{mg} / \mathrm{L}]$ & 2.73 & 4.19 \\
\hline$U_{\text {total }}[\mathrm{mg} / \mathrm{L}]$ & 5.46 & 8.38 \\
\hline$U_{\text {total }}^{\prime}[\%]$ & 6.82 & 10.92 \\
\hline$u_{\text {geochemical }}[\mathrm{mg} / \mathrm{L}]$ & 2.50 & 3.90 \\
\hline$U_{\text {geochemical }}[\mathrm{mg} / \mathrm{L}]$ & 5.00 & 7.80 \\
\hline$U_{\text {geochemical }}^{\prime}[\%]$ & 6.25 & 10.17 \\
\hline$u_{\text {sampling }}[\mathrm{mg} / \mathrm{L}]$ & 0.73 & 0.46 \\
\hline$U_{\text {sampling }}[\mathrm{mg} / \mathrm{L}]$ & 1.46 & 0.91 \\
\hline$U_{\text {sampling }}^{\prime}[\%]$ & $\mathbf{1 . 8 3}$ & $\mathbf{1 . 1 9}$ \\
\hline$u_{\text {analytical }}[\mathrm{mg} / \mathrm{L}]$ & 0.81 & 1.45 \\
\hline$U_{\text {analytical }}[\mathrm{mg} / \mathrm{L}]$ & 1.61 & 2.90 \\
\hline$U_{\text {analytical }}^{\prime}[\%]$ & 2.02 & 3.78 \\
\hline$u_{\text {measurement }}[\mathrm{mg} / \mathrm{L}]$ & 1.09 & 1.52 \\
\hline$U_{\text {measurement }}[\mathrm{mg} / \mathrm{L}]$ & 2.18 & 3.04 \\
\hline$U_{\text {measurement }}^{\prime}[\%]$ & $\mathbf{2 . 7 2}$ & $\mathbf{3 . 9 6}$ \\
\hline
\end{tabular}

Uncertainty connected with sampling for set $\mathrm{S} 1$ is $1.83 \%$ (with average metasilicic acid concentration in analyzed samples $80.02 \mathrm{mg} / \mathrm{L})$, and total uncertainty is $6.82 \%( \pm 5.46$ $\mathrm{mg} / \mathrm{L}$ ). In case of second sampler S2 uncertainty connected with sampling is a little bit lower $-1.19 \%$ (with average metasilicic acid concentration $76.72 \mathrm{mg} / \mathrm{L}$ ), however, total uncertainty is higher $10.92 \%( \pm 8.38 \mathrm{mg} / \mathrm{L})$. Due to the fact that the greater part of total 
uncertainty is geochemical uncertainty, the higher uncertainty for the S2 sampler can be related to the natural variability of the water samples during the study period.

The obtained results indicate that in the case of samples collection by qualified and experienced samplers there is no difference in uncertainty arising from sampling. Also measurement uncertainty for both tested samplers is similar and is much smaller than uncertainty declared by the laboratory. When the uncertainty is estimated using duplicate samples collected by the one person using single sampling procedure, only random effect are included, whereas during uncertainty estimation in the laboratory also systematic errors are considered. The estimation of uncertainty in a reliable manner and then using it during the inference process contribute to increase the reliability of decisions making on the obtained results.

\subsection{Conclusion}

In this research the influence of the samplers change on the uncertainty of the sampling was presented on the example of metasilicic acid analysis in geothermal water samples from Podhale region, southern Poland. In the assessment of total uncertainty the empirical approach was applied, based on normal and duplicate samples analyses. The samples were collected from the same well by two samplers from October 2014 to March 2016. The uncertainty determination was performed using ROBAN software and the analysis of variance with robust statistics (rANOVA). Uncertainty connected with sampling for set S1 is $1.83 \%$ (with average metasilicic acid concentration in analyzed samples $80.02 \mathrm{mg} / \mathrm{l}$ ), and total uncertainty is $6.82 \%( \pm 5.46 \mathrm{mg} / \mathrm{l})$. In case of second sampler S2 uncertainty connected with sampling is lower - $1.19 \%$ (with average metasilicic acid concentration $76.72 \mathrm{mg} / \mathrm{l})$, however, total uncertainty is higher $-10.92 \%( \pm 8.38 \mathrm{mg} / \mathrm{L})$.

The obtained results indicate that in the case of samples collection by qualified and experienced samplers there is no difference in uncertainty arising from sampling and the value of this uncertainty can be reduced. Therefore it is very important to take into account systematic sampling errors connected with the change of sampler. Problem of sampling uncertainty of hydrogeochemical data was mentioned in publications [3, 14-16].

Measurement uncertainty for both samplers is about fourth times smaller than uncertainty declared by the laboratory. When the uncertainty is estimated using duplicate samples collected by the one person using single sampling procedure, only random effects are included. Estimation of uncertainty in the laboratory takes into account both random and systematic errors. The estimation of uncertainty in a reliable manner and then using it during the inference process contribute to increase the reliability of decisions making on the obtained results.

\section{Acknowledgement}

This work was financed by the Polish National Centre for Research and Development, grant no. 245079 (2014-2017).

\section{References}

1. Nielsen D.M. (ed.) (1991) Practical handbook of ground-water monitoring. CRC Press

2. EURACHEM (2007) Measurement uncertainty arising from sampling. A guide to methods and approaches. EURACHEM. 
3. Kmiecik E. (2018) Analytical procedures for ion quantification supporting water treatment process. [In:] Geothermal water management. J. Bundschuh, B. Tomaszewska (eds.), Boca Raton [etc]: CRC Press. Taylor \& Francis Group (Sustainable Water Developments: Resources, Management, Treatment, Efficiency and Reuse; ISSN 2373-7506; vol. 6) ISBN: 978-1-138-02721-3; p. 83-112

4. Wątor K., Kmiecik E., Tomaszewska B. (2016) Assessing medicinal qualities of groundwater from the Busko-Zdrój area (Poland) using the probabilistic method. Environmental Earth Sciences, 75(804), 1-13. DOI: 10.1007/s12665-016-5538-0.

5. Kleszcz A. and Tomaszewska B. (2013) Prognozowanie scalingu na przykładzie wód ujmowanych otworem Bańska PGP-1 [Prediction of scaling phenomenon based on Bańska PGP-1 geothermal well]. Technika Poszukiwań Geologicznych Geotermia, Zrównoważony Rozwój - Geological Exploration Technology Geothermics, Sustainable Development, 1, 115-122 (in Polish).

6. Bujakowski W., Tomaszewska B. and Miecznik M. (2016) The Podhale geothermal reservoir simulation for long-term sustainable production. Renewable Energy 99, 420430.

7. Kępińska B. and Ciągło J. (2008) Możliwości zagospodarowania wód geotermalnych Podhala do celów balneoterapeutycznych i rekreacyjnych [Possibilities of use of the Podhale geothermal waters for balneotherapeutical and recreational purposes]. Geologia,34(3), 541-559 (in Polish).

8. Kmiecik E., Korzec K. and Mika A. (2016) Metasilicic acid in thermal water from Bańska PGP-1 well, Podhale. In: EGC 2016, European Geothermal Congress 2016, Strasbourg, France.

9. Korzec K., Kmiecik E., Mika A., Tomaszewska B. and Wątor K. (2016) Metodyka opróbowania ujęć wód termalnych - aspekty techniczne [Methodology of thermal water sampling - technical aspects]. Technika Poszukiwań Geologicznych Geotermia, Zrównoważony Rozwój - Geological Exploration Technology Geothermics, Sustainable Development, 1, 75-87 (in Polish).

10. Witczak S., Kania J. and Kmiecik E. (2013) Katalog wybranych fizycznych I chemicznych wskaźników zanieczyszczeń wód podziemnych i metod ich oznaczania [Guidebook on selected physical and chemical indicators of groundwater contamination and methods of their determination]. Inspekcja Ochrony Środowiska, Warszawa, ISBN: 978-83-61227-13-7, http://www.gios.gov.pl/images/dokumenty/raporty/ebook2_20130422.pdf (in Polish).

11. ISO 11352 (2012) Water quality. Estimation of measurement uncertainty based on validation and quality control data.

12. Kmiecik E. and Korzec K. (2015) Uncertainty associated with the sampling of geothermal water. [In:] World Geothermal Congress. WGC 2015: views from down under - geothermal in perspective. ed. Roland Horne, Toni Boyd. www.geothermalenergy.org/pdf/IGAstandard/WGC/2015/14037.pdf?

13. Kmiecik E. and Podgórni K. (2009) Ocena wpływu zmiany próbobiorcy na niepewność związaną z opróbowaniem w monitoringu wód podziemnych [Estimation of sampler influence on uncertainty associated with sampling in groundwater monitoring]. Przegląd Geologiczny, 436, 253-260 (in Polish).

14. Kmiecik E. (2018) The Impact of Human Errors on the Estimation of Uncertainty of Measurements in Water Monitoring. In: Boring R. (eds) Advances in Human Error, Reliability, Resilience, and Performance. AHFE 2017. Advances in Intelligent Systems and Computing, vol 589. Springer, Cham doi : 10.1007/978-3-319-60645-3_16. 
15. Ramsey M. H., Thompson M. and Hale M. (1992) Objective evaluation of precision requirements for geochemical analysis using robust analysis of variance. Journal of Geochemical Exploration, 44, 23-26.

16. Ellison S.L.R., Rosslein M. and Williams A. (2000) Quantifying Uncertainty in Analytical Measurement. 2nd edition. EURACHEM/CITAC Guide CG4.

17. Kmiecik E., Tomaszewska B. Wątor K., Bodzek M., Rajca M. and Tyszer M. (2017) Implementation of QA/QC program in research related to the membrane processes use in thermal water treatment. Desalination and Water Treatment 73, 339-347. doi:10.5004/dwt.2017.20604

18. ISO 5667-11 (2011) Water sampling. Part 11. Guidance on groundwater sampling.

19. PN-EN ISO 11885 (2009) Inductively coupled plasma optical emission spectrometry (ICP-OES) 